Лущик Марія Василівна кандидат географічних наук, асистент кафедри туризму, Національний університет «Львівська політехніка», вул. Карпінського 2/4, 1-й навч. к., кім. 210, м. Львів, 79013, тел.: (032) 258-32-26, e-mail: murmarja@gmail.com, https://orcid.org/0000-0001-5411-348X

\title{
ПРО ПОНЯТТЯ ТА ВИДИ ВІЙСЬКОВОГО ТУРИЗМУ
}

Анотація. Події світової історії та сучасні збройні протистояння залишили численні оборонні споруди, місця битв, різноманітні види озброєння, більшість із яких можна розглядати як потужний ресурс для розвитку туризму. Незмінний інтерес людей до військової історії, історичних баталій, битв та іншого надбання військової спадщини популяризує військовий туризм. Проте, попри наявність певного масиву досліджень і публікацій, присвячених різним аспектам розвитку даного виду туризму, фундаментальних досліджень у руслі дефініціювання та класифікації видів військового туризму не виявлено. Тому теоретичні обгрунтування сутності військового туризму як інноваційного напрямку екстремального та пізнавального туризму є своєчасними та актуальними. Для реалізація даної мети було проведено аналіз основних теоретичних положень і принципів функціонування військового туризму, висвітлених у вітчизняних та закордонних наукових публікаціях. Виявлено, що у західній науковій літературі військовий туризм або туризм військової спадщини функціонує поряд із такими термінами, як туризм «на крові», темний туризм і танатуризм, натомість в українській науковій літературі йому відводиться місце серед екстремального, розважального та спеціалізованого видів туризму. На підставі аналізу наукових дискусій та уже запропонованих критеріїв ідентифікації туризму запропоновано військовий туризм розуміти як один із видів туризму, який передбачає відвідування історичних та сучасних пам'ятних військових об'єктів/установ/локацій, залучення туристів до реалій сучасного військового життя і побуту, участь в безпечних військових подіях чи їх історичних реконструкціях тощо. Описано основні мотиви туристів для військового виду подорожей. Подано типізацію основних критеріїв та принципів класифікації військового туризму в туристичній діяльності. Запропоновано авторську класифікацію видів військового туризму, згідно якої виділено військовоісторичний, мілітарі- та військово-подієвий види туризму. 
Ключові слова: військовий туризм, мілітарі-туризм, військове паломництво, військово-історичний туризм, воєнний туризм, військовопригодницький туризм, військово-пізнавальний туризм, військово-історичні реконструкції бойових дій, туризм військової спадщини.

Lushchyk Mariya Vasylivna $\mathrm{PhD}$ in Geography, Assistant of the Department of Tourism, Lviv Polytechnic National University, Karpinskoho 2/4 St., Building 1, Room 210, Lviv, 79013, tel.: (032) 258-32-26, e-mail: murmarja@gmail.com, https://orcid.org/0000-0001-5411-348X.

\section{ON THE CONCEPT AND TYPES OF MILITARY TOURISM}

Abstract. The events of world history and modern armed confrontations have left numerous fortifications, battlefields, various types of weapons, most of which can be considered as a powerful resource for tourism development. The constant interest of people in military history, historical battles, battles and other military heritage promotes military tourism. However, despite the presence of a certain array of research and publications on various aspects of the development of this type of tourism, basic research in the definition and classification of military tourism has not been identified. Therefore, the theoretical justifications of the essence of military tourism as an innovative direction of extreme and cognitive tourism are timely and relevant. To achieve this goal, an analysis of the main theoretical provisions and principles of military tourism, covered in domestic and foreign scientific publications. It has been found that in Western scientific literature, military tourism or military heritage tourism functions alongside such terms as "blood tourism", dark tourism and tanatourism, while in the Ukrainian scientific literature it is given a place among extreme, entertainment and specialized types of tourism. Based on the analysis of scientific discussions and already proposed criteria for tourism identification, it is proposed to understand military tourism as one of the types of tourism, which involves visiting historical and modern military sites / institutions / locations, attracting tourists to the realities of modern military life, in safe military events or their historical reconstructions, etc. The main motives of tourists for military travel are described. The typification of the main criteria and principles of classification of military tourism in tourist activity is given. The author's classification of types of military tourism is offered, according to which military-historical, military and military-event types of tourism are distinguished.

Keywords: military tourism, military-tourism, military pilgrimage, militaryhistorical tourism, military tourism, military-adventure tourism, military-cognitive tourism, military-historical reconstructions of hostilities, military heritage tourism.

Постановка проблеми. Еволюція світової економіки завжди була тісно пов'язана із боротьбою за ресурси, що часто спричиняло численні загарбницькі війни, без яких історія не можлива. 3 тих часів залишились численні оборонні споруди, місця битв, різноманітні види озброєння. Ці атракції $є$ потужним ресурсом для розвитку. Та й сучасні військові об'єкти також дуже часто 
цікавлять туристів. Інтерес до військової історії, історичних баталій та битв у сучасних людей насправді непідробний. Хтось хоче приміряти військовий мундир епохи наполеонівських воєн, хтось бачить себе офіцером або солдатом Другої світової війни і намагається пройти шлях дідів і прадідів. 3 огляду на це військовий туризм останнім часом став досить популярним.

Аналіз останніх досліджень і публікацій. Автором були використані матеріали наукових досліджень вітчизняних та зарубіжних науковців у сфері проблематики військового туризму. Ці питання розглядали О. Любіцева (2008), Р. Шаправский (2010), М. Кляп та Ф. Шандор (2011), А. Мельник (2012), Д. Каднічанський (2013), В. Кушнарьов, О. Поліщук (2018), Н.Корнілова, К. Скупенко (2019) та ін. Попри наявність певного масиву досліджень i публікацій, присвячених різним аспектам розвитку даного виду туризму, фундаментальних досліджень у руслі дефініціювання та структуризації видів військового туризму не виявлено.

Метою статті $є$ теоретичне обгрунтування сутності військового туризму як інноваційного напрямку екстремального та пізнавально-розважального туризму. Методологія дослідження передбачає проведення аналізу основних теоретичних положень i принципів функціонування військового туризму, його місця в туристично-рекреаційній діяльності, обгрунтування завдань та туристичних мотивів для такого виду подорожей, визначення основних критеріїв та принципів класифікації підвидів військового туризму.

Виклад основного матеріалу. Поняття військового туризму недостатньо вивчене. В туризмознавстві не існує усталеного єдиного підходу до визначення цього виду туризму та його класифікації. Це пояснюється тим, що військовий туризм є новим напрямком в туризмі, а також дуже дорогим задоволенням і тому недоступний для широких верств населення.

Іноземна та вітчизняна академічна література містить дуже обмежені відомості щодо трактування суті військового туризму.

На думку Д. Вентера (D. Venter, 2017) у статті «Examining military heritage tourism as a niche tourism market in the South African context», військовий туризм, який автор іменує як «туризм військової спадщини» (military heritage tourism), може бути віднесений до підгрупи туризму спадщини (ред. у вітчизняній літературі - це історико-культурний туризм). Вчений констатує, що туризм військової спадщини не чітко визначений у літературі, та функціонує поряд із такими термінами, як туризм «на крові» (blood tourism), темний туризм (dark tourism) i танатуризм (thanatourism), дефініції яких відповідно висвітлено різними авторами ((Biran \& Hyde, 2013; Farmaki, 2013; Foley \& Lennon, 1996; Raine, 2013; Ryan \& Kohli, 2006; Sharpley \& Stone, 2009; Stone, 2006) [1].

Пізніші дослідження акумулюють в середовище військового туризму концепції туризму смерті, туризму катастроф та туризму аморальності (Skinner, 2012) [1]. Відповідно до Tarlow (2005), темний туризм можна описати як відвідування місць, де трапились трагедії чи історично варті уваги смерті, які продовжують впливати на наші життя [1]. Seaton (1999) описує танатуризм як подорож до місця, повністю або частково мотивоване бажанням реальних або символічних зустрічей зі смертю, особливо, але не лише, насильницькою 
смертю [1]. Принципова різниця між темним туризмом, танатуризмом, кровним туризмом та військовим туризмом - це те, що перші три стосуються будь-якої форми смерті або трагедії, тоді як останній стосується саме військової справи, минувшини та іiі історичної спадщина [1].

На підставі аналізу наукових дискусій та уже запропонованих критеріїв ідентифікації туризму військової спадщини, автор статті пропонує наступне розуміння поняття військового туризму - це подорожі, дослідження або участь у відвідуванні об’єктів воєнної спадщини чи військових заходів, які мають особисте історичне значення, резонанс чи інтерес для відвідувача або туриста, $\mathrm{i}$ не передбачають винагороди.

В. Л. Смim (Valene L. Smith, 1998) у статті «War and tourism: An American ethnography», досліджуючи послідовний розвиток туризму в Сполучених Штатах від Першої світової війни до теперішнього часу та вплив Другої світової війни на закладення основ сучасного масового та чартерного туризму, стверджує, що військовий туризм і пов'язані 3 війною туристичні атракції $\epsilon$ найбільш відвідуваними категоріями туристичних об'єктів, та вважає, що військовий туризм - це найемоційніший спеціалізований вид туризму [2].

У статті «Military tourism» M. Храсовскі та K. Ноерес (2011) вказується, що військовий туризм - це відпочинок, який має військове підгрунтя. Автори виділяють дві складові туризму: продукти, що стосуються військового обладнання і розглядаються як сегмент пригодницького туризму, та продукти, що концентруються на історичних подіях i належать більше до освітнього сегменту туризму. У статті робиться акцент на першу складову, залишаючи останню на другому плані [3].

P. Звідженберг (R. Zwigenberg, 2016) у праці «The Atomic City: Military Tourism and Urban Identity in Postwar Hiroshima» зазначає, що військовий туризм - це сучасний інструмент переосмислення трагедій минулого та уникнення помилок сучасності. Потенційні локації військового туризму мають стати майданчиками історичних реконструкцій та «платформами діалогу і пам'яті». Водночас, автор констатує, що відвідування військових атракцій та місць пам'яті завжди матиме неоднозначне сприйняття суспільством - для одних це місце може бути розвагою, для інших - тісно пов'язане із трагічним досвідом [4].

Важливими категоріями у закордонних наукових дослідженнях військового туризму є поняття військового паломництва (millitary pilgrimage) та туризму баталій (battlefield tourism), які акцентують увагу на вшануванні пам'яті подій, осіб та втрат історичного минулого. Військове паломництво, на відміну від видів та підвидів військового туризму позбавлене розважального аспекту [5].

Як i серед іноземних колег, вітчизняна наукова традиція не має загальновизнаного дефініціювання поняття військового туризму. Існують різноманітні наукові точки зору щодо місця цього виду туризму у світовій системі класифікації видів туризму, а також різноманітні підходи до визначення цього поняття як у науковців, так і в туристичних клубах, які організовують відпочинок у цій сфері.

Так A. Мельник (2012) у праці «Нестандартні види туризму. Особливості функціонування військового туризму» визначає військовий туризм як різновид 
туризму, метою якого є відвідування місцевості, пов’язаної з військовими та воєнними діями [6].

М.Кляп і Ф.Шандор (2011) у праці «Сучасні різновиди туризму» розглядають військовий туризм як туризм на місцях боїв і історичних битв для всіх зацікавлених, а також для ветеранів і родичів загиблих воїнів, відвідання існуючих та історичних військових об'єктів і полігонів, бойових морських кораблів, підводних човнів, катання на військовій техніці, стрільба зі зброї на полігонах і в тирах, участь у військових навчаннях та маневрах, перебування на полігонах в якості глядачів - military tour, а також тури на відвідання воєнних концтаборів та в’язниць [7].

У праці «Туризмознавство» О. Любіцевої (2008) зазначається, що військовий туризм відноситься швидше до розважального, ніж екстремального виду. Автор зазначає, що військовий туризм надає можливість відчути себе в умовах військових навчань чи здійснення бойових дій i полягає в можливості оволодіння туристами навичок водіння бойових машин (танків, БТР тощо), здійснити політ у надзвуковому літаку, стрибнути 3 парашутом або навіть відвідати район бойових дій [8].

Військовий туризм також розглядається у контексті спеціалізованого туризму. Так, B. Кіптенко (2010) у «Менеджменті туризму» визначає спеціалізований туризм як туризм, який здійснюється 3 метою вивчення специфічних особливостей того чи іншого місця, надбання індивідуального досвіду, виконання спортивних нормативів, активного відпочинку та ін. Автор зазначає, що військовий туризм не може відноситись лише до пригодницького чи екстремального, адже у ньому присутні елементи розважальні і пізнавальні. Тому найкраще виділити його в окремий вид спеціалізованого туризму [9].

С. Дутчак та М. Дутчак (1999) в «Туристсько-краєзнавчих дослідженнях» вважають, що спеціалізований туризм - це система окремих сегментів туризму, в основу виділення яких поставлена мета подорожі. Автори виділяють у спеціалізованому туризмі пізнавально-культурно-розважальний туризм як складову, і саме в цьому сегменті бачать місце мілітарі-туризму [10].

B. Абрамов та У. Максюта (2019) вважають, що військовий туризм подорожі в зони бойових зіткнень 3 метою огляду визначних пам'яток і полів битви. Можуть включати польоти на бойових літаках і вертольотах, постріли 3 артилерії та танків, відвідування військово-історичних музеїв й історичних місць бойових дій, а також участь у реконструкціях знаменитих битв [11].

H. Корнілова та К. Скупенко (2019) зазначають, що військовий патріотичний туризм (воєнний туризм, мілітарі туризм) - різновид туризму, метою якого $є$ відвідання місцевості, пов'язаної з військовими та воєнними діями у межах своєї держави. Особливістю військового туризму є відвідання військових частин, штабних та польових навчань, а також вивчення військового побуту, отримання навичок у поводженні зі зброєю та поліпшенні фізичної форми. Це передбачає проживання у військових частинах та проходження вишколу, в тій чи іншій мірі подібного до того, що проходять кадрові військовослужбовці [12].

Таким чином, пропонуємо під військовим туризмом розуміти спеціалізований вид туризму, який в різних формах прояву може містити 
елементи пізнавального, культурно-історичного, екскурсійного, розважально-го, пригодницького, археологічного, екстремального та інших видів туризму, який передбачає: а) відвідування історичних та сучасних пам'ятних військових об'єктів/установ/локацій, б) залучення туристів до реалій сучасного військового життя і побуту, в) участь в безпечних військових подіях чи їх історичних реконструкціях тощио.

Завданнями військового туризму є: збереження в пам'яті народу правдивої інформації про події воєнного часу, про героїчне минуле; розвиток патріотичного виховання молоді за рахунок проведення краєзнавчих екскурсій; створення програм військового туризму, які допомагають розвитку регіонів; сприяння військовим музеям та іншим об'єктам - за рахунок проведених екскурсій покращується їх популярність і фінансування.

Об'єктами військового туризму виступають об'єкти звичайного історичного туризму, які свого часу, крім іншого, мали також мілітарне значення - давні міські укріплення та окремі оборонні споруди, старовинні оборонні та бастіонні замки, численні оборонні монастирі, форти та оборонні лінії. За традиційного підходу під час екскурсійного огляду таких споруд акцент робиться на їх мистецькій та архітектурній цінності, значущості в моментах політичної та соціальної історії, минулого етнічних громад і конфесійних груп. Водночас вони мають велике значення як фортифікаційні споруди, пам'ятки давньої військової історії і можуть служити ключовими об’єктами відвідування для спеціалізованих турів військово туризму.

Інформативною вважаємо типізацію мотивації відвідування об'єктів військової спадщини, розроблену і описану Raine (2013), який виділяє: фактичний, міфічний, соціальний та етнічний мотиваційні контексти [1]:

- фактична (конкретна) мотивація - об'єкти військової спадщини відвідуються 3 метою досягнення об'єктивності та фактичності їхнього військово-туристичного потенціалу. Найбільше актуальна для вчених або істориків, які шукають детальні відповіді на конкретні військові питання та факти, такі як військові стратегії, рухи, сила та склад підрозділу, спорядження, технічні характеристики тощо;

міфічна мотивація - військова спадщина базується на розмитому фактичному тлумаченні події (битва) або характеристики обладнання (наприклад, німецький танк «Тигр» Другої світової війни), яке згодом стає міфічним, перекошеним та відмінним від реальності. Міфічні особливості напряму корелюються з актами героїзму, патріотизму чи надприродних виявів;

соціальна мотивація - військова спадщина подається так, що пояснює факти, суто з академічною інтерпретацією, яка враховує всі погляди/всі сторони. Популярність такої військової спадщина час від часу змінюється залежно від формулювання та ідеологічного використання;

- етнічна мотивація - військова спадщина використовується для підтримки міфічного сприйняття, підтримки соціально виправданого статусукво. Іншими словами, військова спадщина має важливе значення для вірувань етносів, певної нації або групи [1]. 
Magee та Gilmore (2015) [1] визначили три категорії відвідувачів/туристів, які подорожують для огляду об'єктів військової спадщини, а саме:

- ті, хто має особисте відношення до місць військової спадщини, для кого такого роду об'єкти мають особисте та емоційне значення, особиста військова спадщина та відчуття буття пов'язані із власною особистою спадщиною (Biran, Poria \& Oren, 2011). Ці люди не розглядають цей візит як дозвілля (Biran et al. 2011), а прагнуть до глибокого (військовий) досвіду спадщини (Slade, 2003).

- другу групу становлять звичайні туристи, оскільки вони не мають особистого посилання на (військовий) об'єкт спадщини, а лише переглядають його як об’єкт дозвілля. Ці туристи в першу чергу шукають освіти та знань.

- третій тип - це так звані «амбівалентні» туристи, які відвідують об'єкти, щоб «побачити це» - своєрідний список об'єктів «must-visit» [1].

Як і наукових трактувань поняття військового туризму, так і підходів до його поділу на вузькоспеціалізовані види, є кілька.

На думку Д. Каднічанського, М. Каднічанської (2020), щоб визначити місце військового туризму серед інших видів, здійснити його класифікацію, потрібно зрозуміти різницю між термінами «воєнний» та «військовий»: воєнний - стосується до війни, пов'язаний 3 нею; військовий - який стосується війська, військовослужбовця. Отож, авторами пропонується загальний вид туризму, споріднений із відвідуванням воєнно-історичних та військових об'єктів, називати мілітарним (воєнним) туризмом. В свою чергу, мілітарний (воєнний) туризм, на думку авторів, слід розділити на три групи: воєнно-історичний, військовий (військово-пригодницький) та військово-подієвий (див. рис. 1) $[13,14,15]$. 


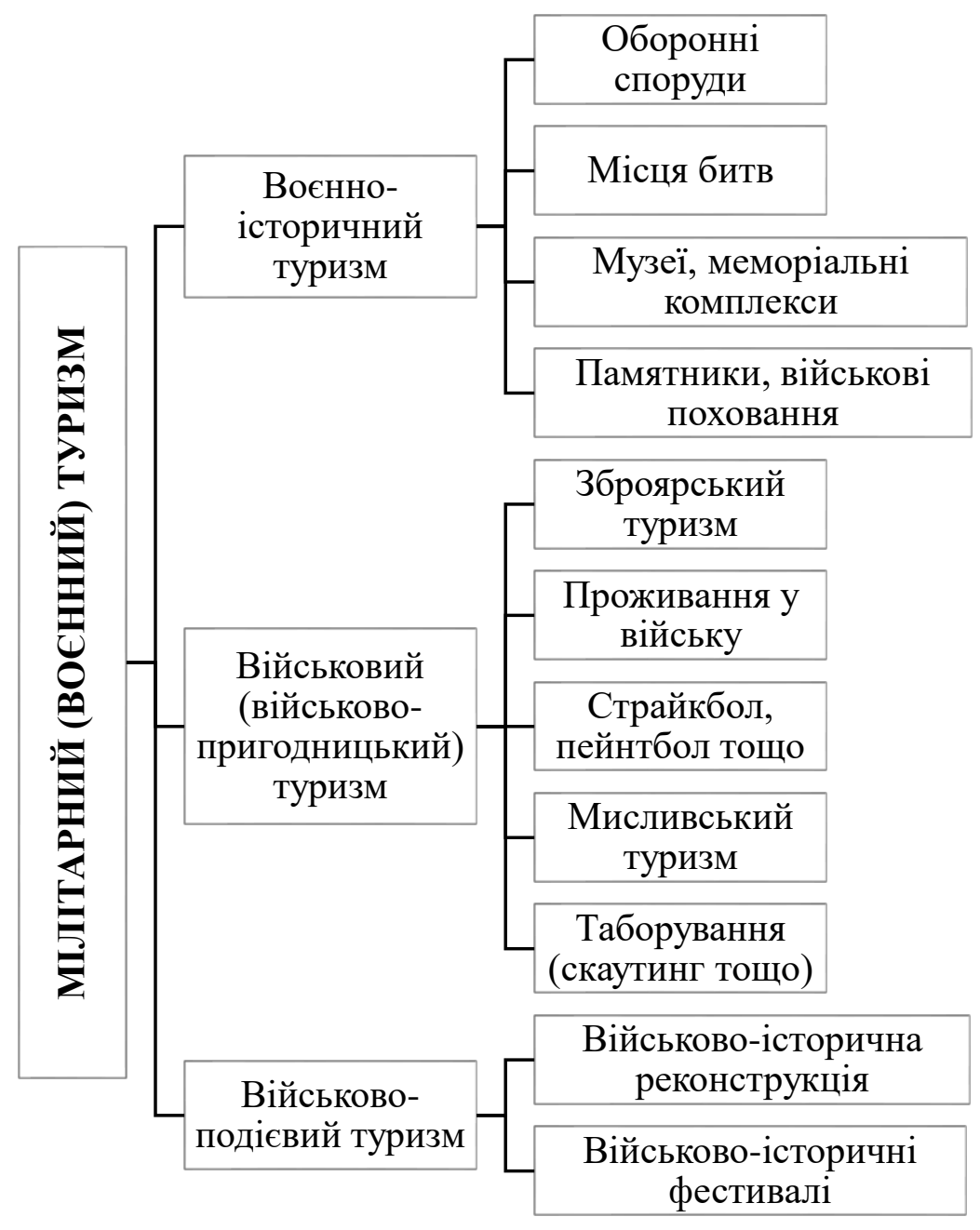

Puc. 1. Класифікація видів військового туризму за Д. та М. Каднічанськими

Автори М. Кляп і Ф.Шандор (2011) у вже згадуваній праці «Сучасні різновиди туризму» поділяють військовий туризм на такі підвиди:

-відвідування історичних місць і музеїв - військово-історичний туризм;

-стрільба з різних видів зброї, стрітбол чи пейтбол, відвідання магазинів зброї та ножів - зброярський туризм;

-життя в армійських умовах і участь у програмах військової підготовки, скаутинг, відвідування різних об'єктів і полігонів, катання на військовій техніці, польоти на військових літаках і вертольотах - мілітарі-туризм;

-відвідування «гарячих» точок планети та місць бойових дій - воєнний туризм [16].

В. Кушнарьов та О. Полішук (2018) стверджують, що якщо військовий туризм стосується історичних битв, військової техніки і споруджень та військової справи в цілому, то можна виокремити такі його види [11]:

-військово-пізнавальний туризм - це відвідування військових музеїв, виставок, конференцій.

-військово-пригодницький туризм - це купівля путівки або туру, що має у комплексі всі послуги щодо забезпечення активного відпочинку з використанням військової техніки та спорядження, відвідування територій та споруд історичних 
бойових дій, морських бойових кораблів, підводних човнів, участь у військових навчаннях та маневрах, тури з визначеним терміном проживання в казармі чи військовій частині.

-військово-історичні реконструкції бойових дій (battlefield tours) відвідування масштабних реконструкцій історичних битв. Сучасна військова реконструкція поєднує історію, тактику бою, різноманітні мілітарні науки, скульптуру, кравецьке ремесло та багато чого іншого, наприклад чимало ентузіастів виготовляють фігурки чи відтворюють реальні бої [11].

Автори зазначають, що існує ще один різновид військового туризму нелегальні тури безпосередньо в зону військового конфлікту. Такі подорожі характеризуються великою небезпекою для туриста і нелегальністю, а отже, великою вартістю, так як безпека клієнта повинна обов'язково гарантуватись відповідальною компанією. На початку 1990-х під час війни в Югославії можна було потрапити у таку зону. У Росії любителів жаги до гострих відчуттів відправлялися до Чечні. Сьогодні у США діють туристичні компанії Warzone Tours та Untamed Borders, які спеціалізуються саме на цьому напрямку. Такі тури організовують до Сирії, Афганістану, Лівану. На нашу думку, це вельми смілива заява -називати перебування в зоні бойових дій не те, що «військовим туризмом», а «туризмом» взагалі. Проте, за соціальними опитуваннями на інтернет-ресурсах, більшість людей розуміють такі подорожі саме під мілітарі-туризмом. Отже, цілком раціонально віднести відвідування зони бойових дій до підвиду екстремального туризму, адже він має всі характеристики саме цього виду туризму.

Існує можливість класифікувати військовий туризм як відвідування місцевості, пов'язаної з військовими та бойовими діями за ознаками активних і пасивних видів діяльності у процесі самого туру, що можна побачити на рис. 2. [17].

Спочатку можна виділити активні і пасивні форми військового туризму. Активна форма туризму спрямована на вдосконалення і розвиток фізичних сил туриста і передбачає активні способи пересування. До таких можна віднести участь в екстремальних польотах на бойових літаках і підготовка до таких програм, участь в ігрових турах, в програмах виживання. 


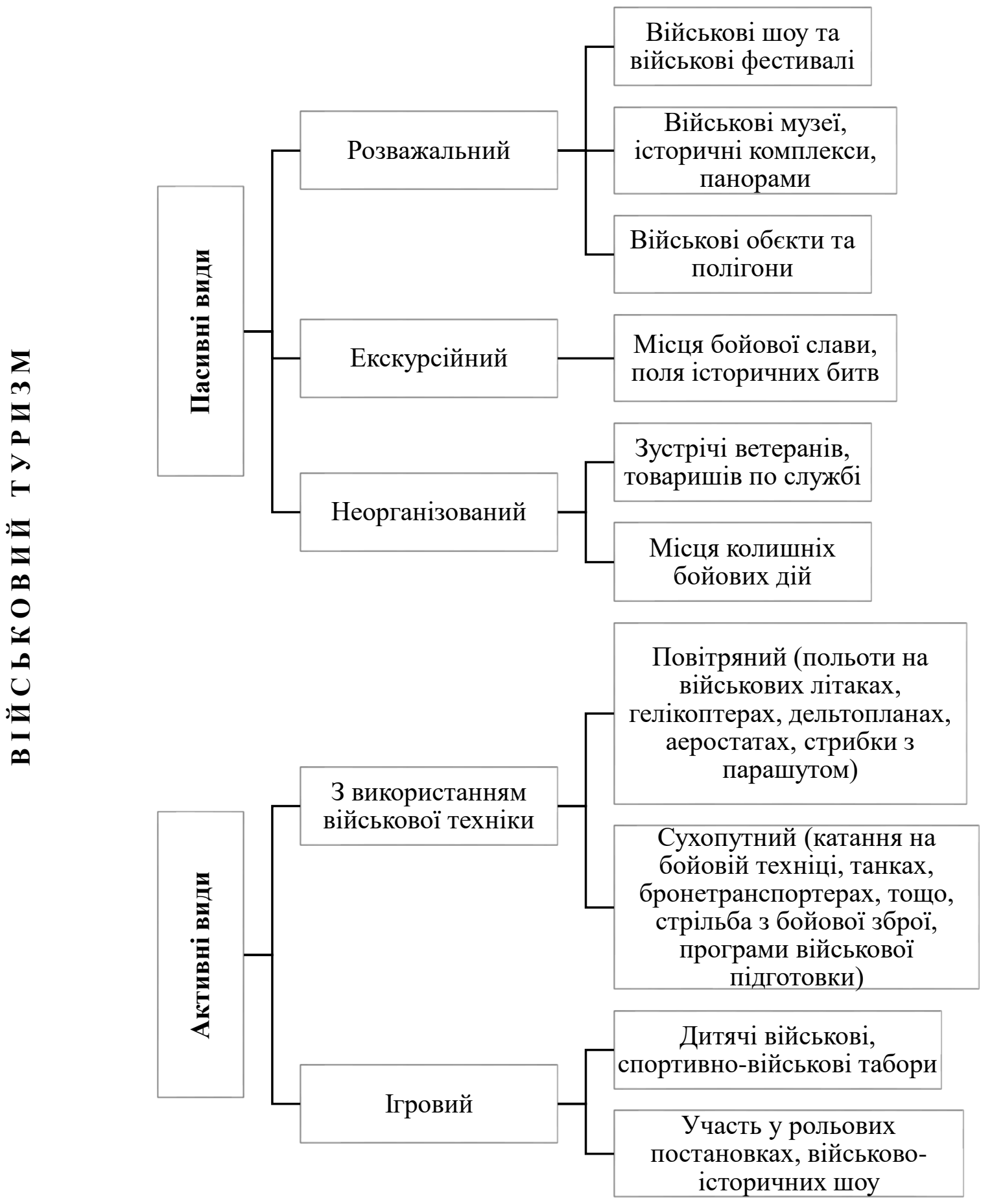

\section{Puс. 2. Види військового туризму за Є. Солошенко}

Пасивний військовий туризм спрямований на задоволення потреб у знаннях, отримання нових вражень і не пов'язаний із застосуванням фізичних сил туриста. Крім активної і пасивної форм військового туризму, можна виділити ігрові форми (пейнтбол, дитячі патріотичні спортивні ігри-фестивалі «Сурми звитяги», «Зірниця») i технічні (із застосуванням військової техніки), організовані і неорганізовані види військового туризму. До неорганізованого туризму відносяться поїздки, які проводяться часто спонтанно і без участі організації-посередника. До таких подорожей можна віднести поїздки туристами в зони бойових дій, зустрічі ветеранів, колишніх товаришів по службі (братів по 
зброї) і т.д., які, зустрічаючись, відвідують місця свого бойового минулого або могили загиблих друзів. Ці зустрічі не мають чіткої програми і варіюються в залежності від побажань самих туристів і їх фінансового становища [17].

На нашу думку, військовий туризм варто поділяти на три функціональні групи: військово-історичний туризм, мілітарі-туризм та військово-подієвий туризм. До військово-історичного туризму належатимуть тури, метою яких буде знайомство 3 військовою історією та вшанування пам'яті загиблих, шляхом відвідування: оборонних укріплень - від найдавніших до сучасних (оборонні вали), споруд прямого військово-оборонного значення та споруд 3 елементами оборонного значення, територій та місцевостей історичних і сучасних битв, боїв, падінь військових літаків, локацій, пов'язаних із героїчними постатями, спеціально обладнаних для експозицій військових цінностей установ та територій військових поховань.

Мілітарі-туризм - це спеціалізований вид військового туризму, який поєднує елементи розважального, пригодницького, екстремального та ігрового видів туризму та має на меті отримання гострих емоцій від долучення до певних видів військової діяльності, побуту військових буднів. Цей вид військового туризму передбачає: технічні можливості - постріляти із зброї: бойової снайперської гвинтівки, карабіна СКС, легендарних «Калашникова», нагана, ТТ та кулемету НСВ, покататися на танках, БТРах, здійснити польоти здійснюються на діючих військових винищувачах та штурмовиках СУ-27УБ, Міг-29УБ, Л- 39, вертольоті MI-8 і т.д.; спортивно-фізичні експерименти - майстер-класи із рукопашного бою та зі стрільби, побутові послуги - оренда тематичних місць для проживання, знайомство з польовою кухнею, пошук місця для проведення військово - спортивних змагань.

Військово-подієвий туризм передбачає активну участь в безпечних подіях військового характеру (географічно - обов'язково поза лінією фронту), або їх театральних постановках чи історичних реконструкціях. Військові події можуть бути як урочистого, святкового (військові паради 3 нагоди державних свят, паради та виставки військової техніки, смолоскипні та памятні ходи, марші звитяги) так i розважального, інтерактивного-ігрового характеру (фестивалі бойового мистецтва, лучні турніри, козацькі забави, бугурти, змагання та чемпіонати історичного бою, історичні реконструкції, військові театралізовані карнавали та спортивно-патріотичні ігри).

Висновки. На сьогоднішній день поняття військового туризму та його місце в системі туризму недостатньо досліджене. Це пояснюється тим, що військовий туризм є новим напрямком в туризмі, а також недоступний для широких верств населення. Військовий туризм розглядають як складову спеціалізованого туризму, а точніше - пізнавального, екстремального, пригодницького та розважального. Існують різноманітні наукові точки зору щодо місця цього виду туризму у світовій та вітчизняній системі класифікації видів туризму. На підставі аналізу наукових дискусій та уже запропонованих критеріїв ідентифікації туризму запропоновано військовий туризм розуміти як один із видів туризму, який передбачає відвідування історичних та сучасних пам'ятних військових об'єктів/установ/локацій, залучення туристів до реалій сучасного військового 
життя i побуту, участь в безпечних військових подіях чи їх історичних реконструкціях тощо. Серед завдань військового тризму уточнено його важливість перш за все для патріотичного виховання молоді, особливо в сучасних умовах, коли героїзм і волелюбність предків оживає в українських воїнах, які боронять країну від російської агресії. Описано основні мотиви туристів, а також типізація відвідувачів, які віддають перевагу турам військової тематики. Подано варіанти класифікації військового туризму в туристичній діяльності. Також запропонована авторська класифікація підвидів військового туризму: військово-історичний туризм; мілітарі-туризм; військово-подієвий туризм.

\section{Лimepamypa:}

1. Venter, D. (2017). Examining military heritage tourism as a niche tourism market in the South African context. African Journal of Hospitality, Tourism and Leisure, Volume, 6 (1).

2. Smith, V. L. (1998). War and tourism: An American ethnography. Annals of Tourism Research, 25 (1), 202-227. https://doi.org/10.1016/S0160-7383(97)00086-8

3. Hrusovsky, M., Noeres, K. (2011). Military tourism. The Long Tail of Tourism: Holiday Niches and their Impact on Mainstream Tourism (pp. 87-94). Wiesbaden: Gabler.

4. Zwigenberg, R. (2016). The Atomic City: Military Tourism and Urban Identity in Postwar Hiroshima. American Quarterly. Johns Hopkins University Press, 68 (3), 617-642. 10.1353/aq.2016.0056.

5. Eade, J., Katić, M. (Eds.). (2017). Military Pilgrimage and Battlefield Tourism: Commemorating the Dead (Routledge Studies in Pilgrimage, Religious Travel and Tourism). 1st Edition.

6. Мельник, А. (2011) Нестандартні види туризму: особливості функціонування військового туризму. Київський збірник наукових пращь Військового інституту Київського наиіонального університету імені Тараса Шевченка, 33, 350-353.

7. Шандор, Ф. (2013). Сучасні різновиди туризму. Київ: Знання.

8. Любіцева, О., Бабарицька, В. (2008). Туризмознавство: вступ до фаху. Київ: Видавничополіграфічний центр «Київський університет».

9. Кіптенко, В. (2010). Менеджмент туризму. Київ: Знання.

10. Дугчак, С., Дутчак, М. (1999). Деякі аспекти виділення сегментів спеціалізованого туризму та їх стан на території Чернівецької області. Туристсько-краєзнавчі дослідження, 2, 123-136.

11. Кушнарьов, В., Поліщук, О. (2018). Мілітарі-туризм як інноваційний напрямок екстримального та пізнавально-розважального туризму. Вісник Київського наиіонального університету культури і мистещтв, 1, 107-118. DOI: 10.31866/2616-7603.1.2018.151825.

12. Корнілова, Н., Скупенко, К. (2019). Військово-патріотичні тури - сучасний напрямок внутрішнього туризму. Матеріали Х Міжнародної науково-практичної конференцї «Туристичний та готельно-ресторанний бізнес в Украӥні: проблеми розвитку та регулювання», 21-22 березня 2019 року, м. Черкаси [Електронний ресурс]: у 2-х томах. Черкаси: ЧДТУ.

13. Каднічанський, Д., Каднічанська, М. (2020). Мілітарний туризм: проблематика термінології та класифікації. Географія, економіка і туризм: наџіональний та міжнародний досвід: Матеріали XIV Міжнародної наукової конферениії, 9 жовтня 2020, 132-135.

14. Каднічанський, Д. (2009). Історична спадщина УПА і туризм. Географія $і$ туризм: європейський досвід, 63-66.

15. Гуржій, О., Пилявець, О. (2009). Сучасна воєнно-історична та воєнна термінологія: проблемні питання. Сторінки воєнної історії України: Збірник наукових статей, 12, 19-24.

16. Кляп, М., Шандор, Ф. (2011). Сучасні різновиди туризму. Київ: Знання.

17 Солошенко, Є. (2019). Диверсифікаиія послуг у сфері військово-історичного туризму. Харків.Взято $3 \mathrm{http}: / /$ dspace.htei.kh.ua:8080/bitstream/123456789/66/1/\%D0\%A1\% D0\%BE\%D0\% BB\%D0\%BE\%D1 \%88\%D0\%B5\%D0\%BD\%D0\%BA\%D0\%BE.pdf. 


\section{References:}

1. Venter, D. (2017). Examining military heritage tourism as a niche tourism market in the South African context. African Journal of Hospitality, Tourism and Leisure, Volume, 6 (1). [in English].

2. Smith, V. L. (1998). War and tourism: An American ethnography. Annals of Tourism Research, 25 (1), 202-227. https://doi.org/10.1016/S0160-7383(97)00086-8. [in English].

3. Hrusovsky, M., Noeres, K. (2011). Military tourism. The Long Tail of Tourism: Holiday Niches and their Impact on Mainstream Tourism (pp. 87-94). Wiesbaden: Gabler. [in English].

4. Zwigenberg, R. (2016). The Atomic City: Military Tourism and Urban Identity in Postwar Hiroshima. American Quarterly. Johns Hopkins University Press, 68 (3), 617-642. 10.1353/aq.2016.0056. [in English].

5. Eade, J., Katić, M. (Eds.). (2017). Military Pilgrimage and Battlefield Tourism: Commemorating the Dead (Routledge Studies in Pilgrimage, Religious Travel and Tourism). 1st Edition. [in English].

6. Melnyk, A. (2011). Nestandartni vydy turyzmu: osoblyvosti funktsionuvannia viiskovoho turyzmu. [Non-standard types of tourism: features of military tourism]. Kyivskyi zbirnyk naukovykh prats Viiskovoho instytutu Kyivskoho natsionalnoho universytetu imeni Tarasa Shevchenka - Kyiv Collection of Scientific Papers of the Military Institute of the Taras Shevchenko National University of Kyiv, 33, 350-353. [in Ukrainian].

7. Sandor, F. (2013). Suchasni riznovydy turyzmu [Modern varieties of tourism]. Kyiv: Knowledge. [in Ukrainian].

8. Lyubitseva, O., Babaritska, V. (2008). Turyzmoznavstvo: vstup do fakhu. [Tourism: introduction to the profession]. Kyiv: Kyiv University Publishing and Printing Center. [In Ukrainian].

9. Kiptenko, V. (2010). Menedzhment turyzmu. [Tourism management]. Kyiv: Znannia. [in Ukrainian].

10. Dutchak, S., Dutchak, M. (1999). Deiaki aspekty vydilennia sehmentiv spetsializovanoho turyzmu ta yikh stan na terytorii Chernivetskoi oblasti. Turystsko-kraieznavchi doslidzhennia [Tourist and local lore research], 2, 123-136. [in Ukrainian].

11. Kushnarov, V., Polishchuk, O. (2018). Militari-turyzm yak innovatsiinyi napriamok ekstrymalnoho ta piznavalno-rozvazhalnoho turyzmu. Visnyk Kyivskoho natsionalnoho universytetu kultury i mystetstv - Bulletin of the Kyiv National University of Culture and Arts, 1, 107-118. DOI: 10.31866/26167603.1.2018.151825. [in Ukrainian].

12. Kornilova, N., Skupenko, K. (2019). Viiskovo-patriotychni tury - suchasnyi napriamok vnutrishnoho turyzmu. [Military-patriotic tours - a modern direction of domestic tourism]. Materialy $X$ Mizhnarodnoi naukovo-praktychnoi konferentsii "Turystychnyi ta hotelno-restorannyi biznes $v$ Ukraini: problemy rozvytku ta rehuliuvannia», 21-22 bereznia 2019 roku - Proceedings of the X International scientific-practical conference "Tourism and hotel and restaurant business in Ukraine: problems of development and regulation», March 21-22, 2019, m. Cherkasy [Elektronnyi resurs]: u 2-kh tomakh. Cherkasy: ChDTU. [in Ukrainian].

13. Kadnichanskyi, D., Kadnichanska, M. (2020). Militarnyi turyzm: problematyka terminolohii ta klasyfikatsii. [Military tourism: issues of terminology and classification]. Heohrafiia, ekonomika i turyzm: natsionalnyi ta mizhnarodnyi dosvid: Materialy XIV Mizhnarodnoi naukovoi konferentsii, 9 zhovtnia 2020 Geography, Economics and Tourism: National and International Experience: Proceedings of the XIV International Scientific Conference, October 9, 2020, 132-135. [in Ukrainian].

14. Kadnichanskyi, D. (2009). Istorychna spadshchyna UPA i turyzm [Historical heritage of the Ukrainian Insurgent Army and tourism]. Heohrafiia $i$ turyzm: yevropeiskyi dosvid - Geography and Tourism: European Experience, 63-66. [in Ukrainian].

15. Hurzhii, O., Pyliavets, O. (2009). Suchasna voienno-istorychna ta voienna terminolohiia: problemni pytannia. [Modern military-historical and military terminology: problematic issues]. Storinky voiennoi istorii Ukrainy: Zbirnyk naukovykh statei - Pages of military history of Ukraine: Collection of scientific articles, 12, 19-24. [in Ukrainian].

16. Kliap, M., Shandor, F. (2011). Suchasni riznovydy turyzmu. [Modern varieties of tourism]. Kyiv: Znannia [in Ukrainian]. 
17. Soloshenko, Ye. (2019). Dyversyfikatsiia posluh u sferi viiskovo-istorychnoho turyzmu [Diversification of services in the field of military-historical tourism]. Kharkiv. Vziato $\mathrm{z}$ http://dspace.htei.kh.ua:8080/bitstream/123456789/66/1/\%D0\%A1\% D0\%BE\%D0\%BB\%D0\%BE\%D1 \%88\%D0\%B5\%D0\%BD\%D0\%BA\%D0\%BE.pdf. [in Ukrainian]. 